\title{
Graphene for Biomedical Applications: A Review
}

(Grafin untuk Aplikasi Bioperubatan: Suatu Sorotan)

\author{
AZRUL AZLAN HAMZAH*, REENA SRI SELVARAJAN \& BURHANUDDIN YEOP MAJLIS
}

\author{
ABSTRACT
}

Since its discovery in 2004, graphene has enticed engineers and researchers from various fields to explore its possibilities to be incepted into various devices and applications. Graphene is deemed a 'super' material by researchers due to its extraordinary strength, extremely high surface-to-mass ratio and superconducting properties. Nonetheless, graphene has yet to find plausible footing as an electronics material. In biomedical field, graphene has proved useful in tissue engineering, drug delivery, cancer teraphy, as a component in power unit for biomedical implants and devices and as a vital component in biosensors. Graphene is used as scaffolding for tissue regeneration in stem cell tissue engineering, as active electrodes in supercapacitor for powering wearable and implantable biomedical devices and as detectors in biosensors. In tissue engineering, the extreme strength of monolayer graphene enables it to hold stem cell tissues as scaffold during in-vitro cell regeneration process. In MEMS supercapacitor, graphene's extremely high surface-to-mass ratio enables it to be used as electrodes in order to increase the power unit's energy and power densities. A small yet having high energy and power densities cell is needed to power often space constrainted biomedical devices. In FET biosensors, graphene acts as detector electrodes, owing to its superconductivity property. Graphene detector electrodes is capable of detecting target molecules at a concentration level as low as 1 pM, making it the most sensitive biosensor available today. Graphene continues to envisage unique and exciting applications for biomedical field, prompting continuous research which results and implementation could benefit the general public in decades to come.

Keywords: Biomedical applications; FET biosensor; graphene; scaffolding; supercapacitor; tissue engineering

\section{ABSTRAK}

Sejak penemuannya pada tahun 2004, grafin telah menarik minat para jurutera dan penyelidik daripada pelbagai bidang untuk mengkaji kebolehaplikasiannya di dalam pelbagai peranti dan penggunaan. Grafin dianggap sebagai bahan super oleh penyelidik disebabkan kekuatannya yang amat tinggi, nisbah luas permukaan kepada jisim yang sangat besar dan sifat superkonduktornya. Walau bagaimanapun, grafin masih belum diakui sebagai bahan elektronik. Di dalam bidang bioperubatan, grafin telah digunakan di dalam kejuruteraaan tisu, penyampaian ubat, rawatan kanser, sebagai komponen unit kuasa untuk implan dan peranti bioperubatan dan sebagai komponen penting di dalam pengesan bio. Grafin digunakan sebagai perancah untuk pembinaan semula tisu di dalam kejuruteraan tisu sel induk, sebagai elektrod aktif di dalam superkapasitor untuk menghidupkan peranti bioperubatan bolehpakai dan implan serta sebagai unsur pengesanan di dalam pengesan bio. Di dalam bidang kejuruteraan tisu, kekuatan grafin selapis yang amat tinggi membolehkannya memegang tisu-tisu sel induk sebagai perancah semasa proses pertumbuhan semula sel secara in-vitro. Di dalam superkapasitor MEMS, nisbah luas permukaan kepada jisim grafin yang tinggi membolehkan penggunaannya sebagai elektrod untuk meningkatkan ketumpatan tenaga dan kuasa unit tersebut. Sel kuasa yang kecil tetapi mempunyai ketumpatan tenaga dan kuasa yang tinggi sering diperlukan di dalam peranti bioperubatan yang acapkali terbatas oleh saiz yang kecil. Di dalam pengesan bio FET, grafin yang mempunyai sifat konduktiviti super berfungsi sebagai elektrod pengesan. Elektrod pengesan grafin boleh mengesan molekul sasaran dengan kepekatan serendah 1 pM, menjadikannya pengesan bio paling sensitif pada masa kini. Grafin terus merealisasikan kegunaan unik dan menarik di dalam bidang bioperubatan, yang seterusnya menarik minat para penyelidik untuk terus menghasilkan penggunaan yang berguna untuk masyarakat pada masa akan datang.

Kata kunci: Aplikasi bioperubatan; grafin; kejuruteraan tisu; pengesan bio FET; sokongan; superkapasitor

\section{INTRODUCTION}

Graphene is an allotrope of carbon which is made up of monolayer of sp2 bonded carbon atoms arranged in honeycomb lattice (Tran \& Mulchandani 2016; Wang et al. 2015). The carbon-carbon (C-C) bond is the basic bonding in graphene, with bond length of approximately $0.142 \mathrm{~nm}$ (Yan et al. 2014). Graphene is the basic building block for many other carbon allotropes such as carbon nanotubes and graphite (Yan et al. 2014). Graphene can be swaddled into zero dimensional fullerenes, rolled into 
carbon nanotubes (CNT) and found in nature as loosely stacked form called graphite (Figure 1). First pristine graphene was successfully produced by mechanical exfoliation and electrically characterized in 2004 by Andre Geim and Konstantin Novoselov at the University of Manchester (Castro Neto et al. 2009). Until recently, researchers faced difficulties in obtaining large surface area graphene films using mechanical exfoliation technique. Thus, in synthesizing graphene, many researchers studied and experimented approaches such as chemical vapor deposition (CVD) on metal substrates (Huang et al. 2010), epitaxial growth on $\mathrm{SiC}$ (Hass et al. 2008) and reduction from graphene oxide flakes (Pei \& Cheng 2012). Graphene fabricated by CVD demonstrated distinguished properties as large-area and high-quality single or few layers graphene has been successfully produced (Bae et al. 2010).
Charge carriers in single layer graphene follows linear energy dispersion relation and behave as chiral massless particles (Dirac Fermions) (Craciun et al. 2011). Bands in single layer graphene touch at two-conical points $\left(\mathrm{K} \& \mathrm{~K}^{\prime}\right)$ in Brillouin zone (Figure 2) as it exhibits zero band gaps in its physical structure. These two independent points, $\mathrm{K}$ and $\mathrm{K}^{\prime}$ in Brillouin zone are known as notch where valence and conductance band touches (Craciun et al. 2011). This allows single layer graphene to demonstrate ambipolar characteristics, where charge carriers can alternate from holes to electrons based on the gate voltage applied at room and low temperature. Novoselov et al. (2007) experimented and proved that charge carriers in single layer graphene behave as Dirac fermions and complied to quantum half effect (QHE), which makes it unique in electronic. However, charge carriers in bi-layer graphene exhibits finite mass

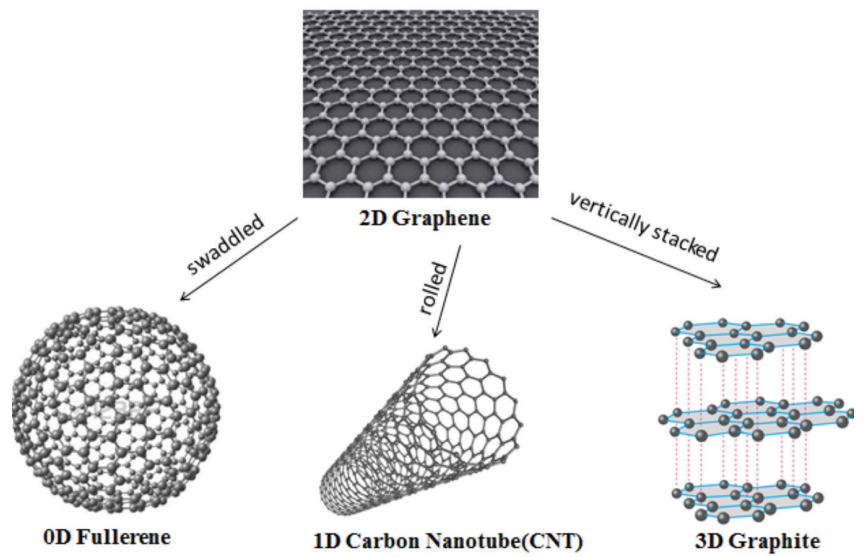

FIGURE 1. Graphene as the building block for many other carbon allotropes

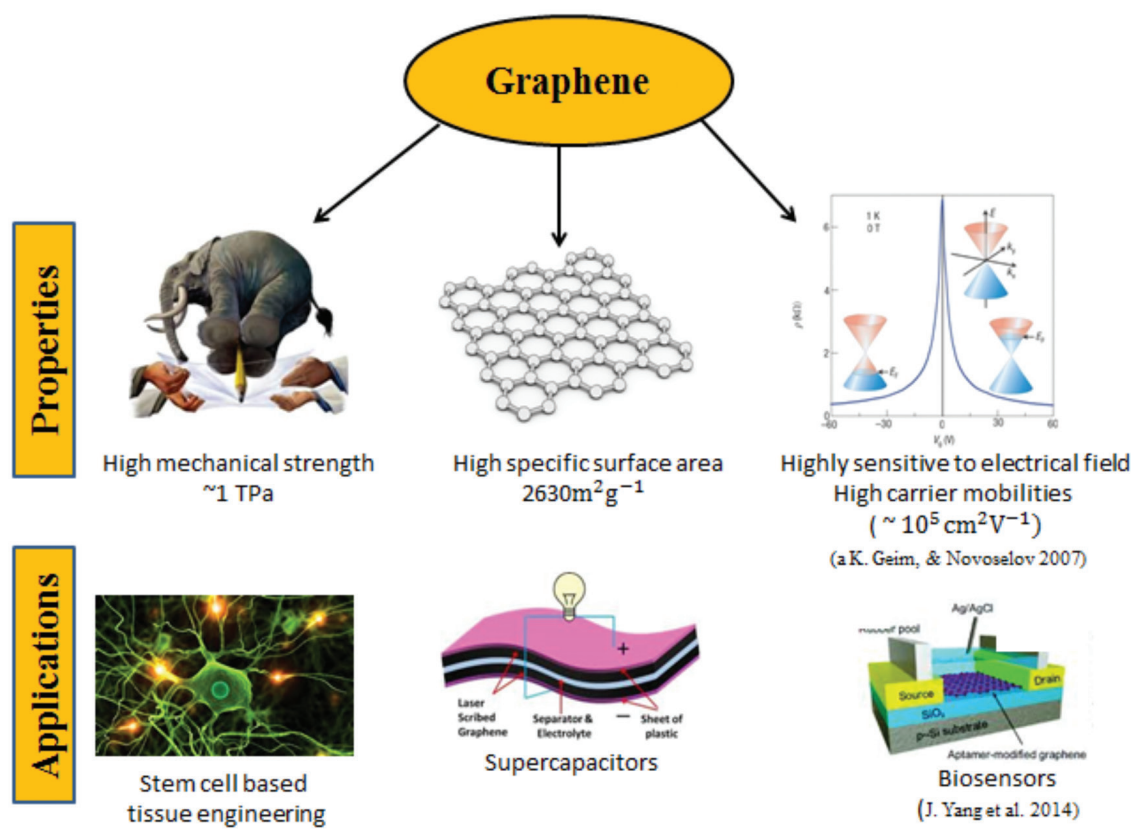

FIGURE 2. Schematic overview of unique properties of graphene and its application in biomedical applications 
called massive Dirac fermions at charge neutrality point. This is because parabolic bands in bi-layer graphene are in contact at $\mathrm{K}$ and $\mathrm{K}$ ' points and shows a gapless state (Table 1). Hence, it remains as metallic at the neutrality points and experiments conducted by researchers showed that bi-layer graphene showed a gate-tunable band gap (Peres 2009). In contrast, trilayer graphene is the only semimetal where conductance and valence bands are overlapped with each other. Besides, comprehensive review on structures of graphene showed that metallic properties of graphene increases with the increasing number of layers in its structures up to several layers (Taychatanapat et al. 2011). At higher level stacking, graphene architectures with more than 10 layers behaves more like bulk graphite and loses graphene's unique electrical properties (Choi et al. 2010; Rakheja \& Sengupta 2016).

In biomedical field, graphene have been utilized as scaffolding in tissue engineering, as an internal component of power unit for biomedical devices, in drug delivery and cancer therapy and in biosensors, due to its ultra-high sensitivity, unique morphological characteristics and strong mechanical properties. The unique monoatomic structure of graphene offers remarkable physical properties such as high mechanical strength with 1 TPa Young's Modulus and $130 \mathrm{G} \mathrm{Pa}$ tensile strength for single graphene layer (Hwang et al. 2013), high transparency of $97.7 \%$ for single layer, high conductivity and high carrier mobilities up to $10^{5} \mathrm{~cm}^{2} \mathrm{~V}^{-1} \mathrm{~s}^{-1}$, which is $2-3$ orders of magnitude higher than the conventional semiconductor such as silicon (Hwang et al. 2013). These excellent physical properties are advantageous in biomedical applications, particularly in tissue engineering, where graphene is utilized as a scaffolds for tissue growth (Goenka et al. 2014). In addition, extremely large surface area to volume ratio, with high conductivity and high carrier mobilities makes it an enticing material for supercapacitors (Tan \& Lee 2013). Furthermore, graphene is a bio inert and chemically robust material. Chemical stability of graphene eliminates the need of electrical passivation as it resists oxidation in solution under low voltage. Apart from this, the distinctive electronic properties of graphene hold advantages particularly in bio sensing application as graphene is highly sensitive to electric field and its surrounding charges as each atom on its carbon sheet is

TABLE 1. Comparison of structural properties of single, bi and trilayer graphene

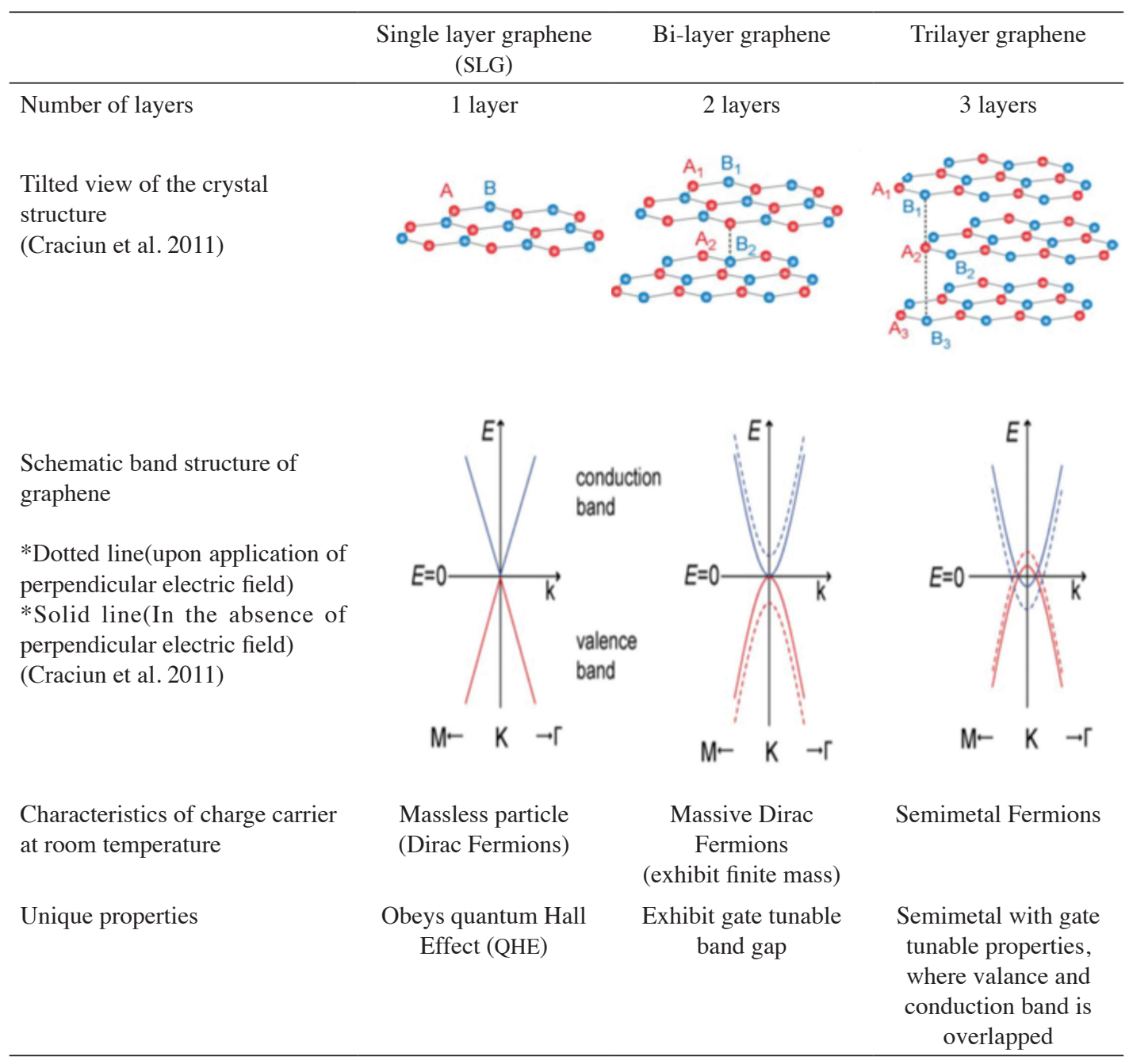


exposed to the environment. Thus, graphene is favored for sensitive detection of analytes in biosensing applications (Figure 3).

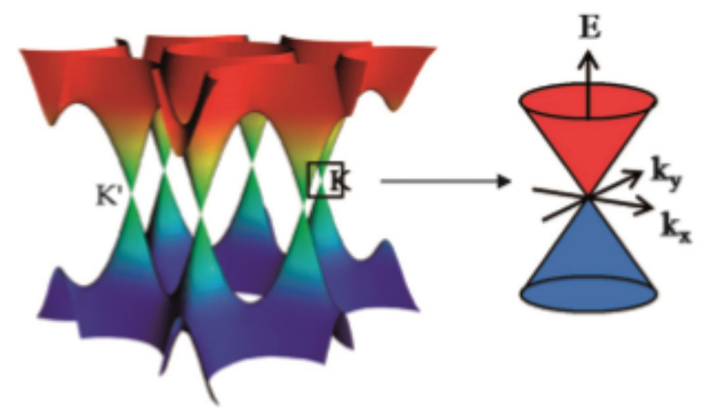

FIGURE 3. Electronic band structure of single layer graphene (Choi et al. 2010)

In terms of patents, up to 2015 , there are in excess of 6,000 graphene patents filed worldwide. Most of the patents are filed within the United States, United Kingdom, the EU, South Korea, Japan and China. The global graphene market is expected to reach USD 113.7 million by 2020 , with a growth rate of $34.8 \%$ per annum (Figure 4) (Innova Research 2015). Rudimentary products such as graphene oxide, monolayer and bi-layer graphene are the most tradable carbon nanomaterials in the market and are expected to make consequential revenue by 2020. Energy segment, especially superconductors and batteries, is the fastest growing graphene application. Asia Pacific region, led by China, demonstrates a rapid growth in graphene market. In 2015, graphene market in China exceeded RMB500 million, which is approximately $25 \%$ of the global market during that period. The dominance of Asia Pacific region is due to the presence of large graphite mines and aggressive graphene research in China and involvement of India, Japan and Korea in graphene electronics applications. China has rapidly increases its production of large area graphene films in the past three years. Figure 5 shows the comparison of quality and cost of graphene products manufactured by different methods (Ren \& Cheng 2014). The current market trend is expected to continue for the next five to ten years.

The unique properties of graphene from the standpoint of mechanical, electrical and morphological characteristics will be explored in this paper. Application of these properties in biomedical applications such as in tissue engineering, supercapacitors for biomedical devices and biosensors (for DNA, pathogens, protein and small molecules detection) will be explored and discussed. Furthermore, outlook and limitations of practical use of graphene based devices will be presented in the final section of this paper.

\section{GRAPHENE AS SCAFFOLDING FOR STEM CELL BASED TISSUE ENGINEERING}

Tissue engineering is a multifaceted field that replaces damaged tissues with biological substitutes which can maintain, restore and improve function of corresponding native tissues. Cells are the role player in the regeneration of tissues and organ. Generally, differentiation of cells were used in tissue regeneration. Stem cells have been used widely as it provides long term proliferation, self-renewal and differentiation into multiple types of cells (Ahadian et al. 2016). Extracellular matrix (ECM) is vital in providing mechanical support and biological cues for cells. Utilizing graphene based scaffold is excellent on stem cell culture as it mimics and recreates ECM for cells in vitro. Therefore, graphene based scaffold has excellent mechanical properties which enabled sustained proliferation, proper adhesion and enhanced differentiation in stem cell based tissue engineering. Among the diverse stem cells, neural stem cells (NSCs) and neural differentiation on graphene

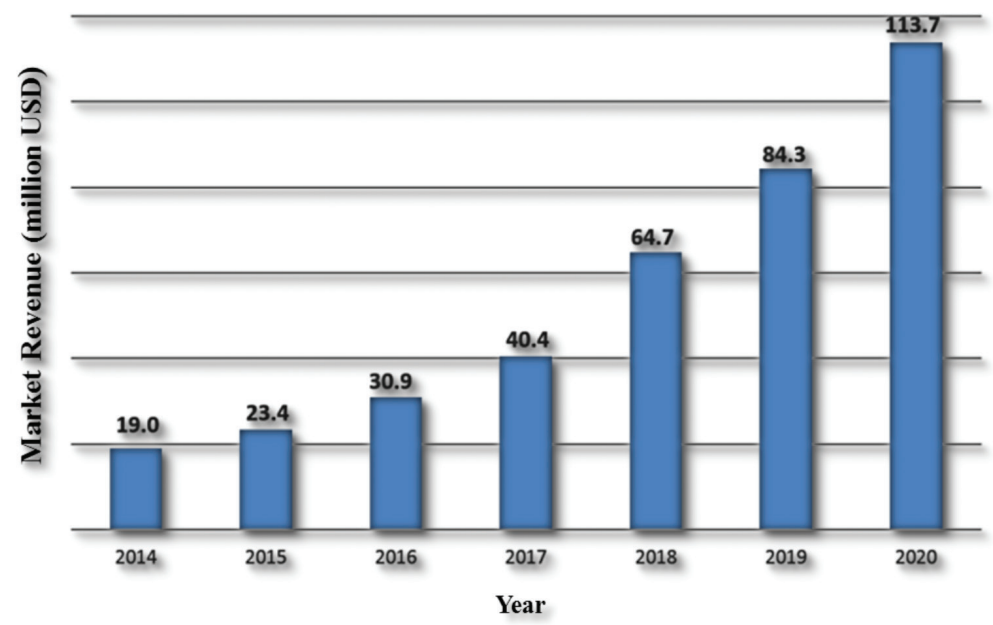

FIGURE 4. Global graphene market revenues (and forecast). The revenue is forecasted to grow at 34.8\% from 2014 to 2020 (Innova Research 2015) 


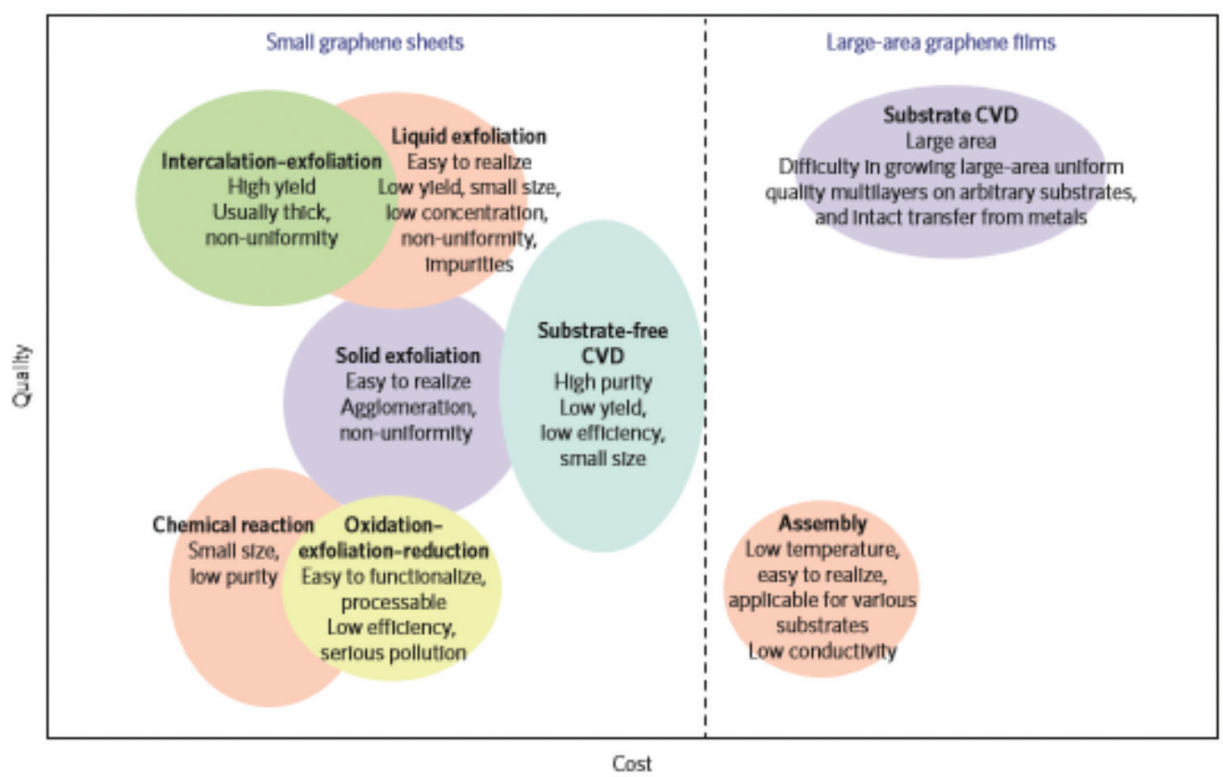

FIGURE 5. Comparison of quality and cost of graphene products manufactured by different methods (Ren \& Cheng 2014)

have emerged promisingly as it realizes the regeneration therapy of varies neurological disorders and diseases (Figure 6) (Akhavan 2016). In neural tissue engineering, NSCs have the ability to differentiate into neural and glial cells and acts as a crucial element in the regeneration of neural tissues. Poly (L-lactide) acid (PLLA) and collagen are the common nanomaterial scaffolds used for proliferation and differentiation of NSCs (Lund et al. 2009; Yang et al. 2005). However, these nanomaterials are not electrically conductive and not highly efficient in differentiating NSCs into neural cells. This limitation outstands graphene to be effectively utilized in neural tissue engineering as it has high electrical conductivity and tunable electronic properties.

Differentiation of human neural stem cells (hNSC) towards neurons rather than glial cells determines the success of stem cell therapy. Park et al. (2011) have showed that (hNSC) cultured on graphene differentiated more

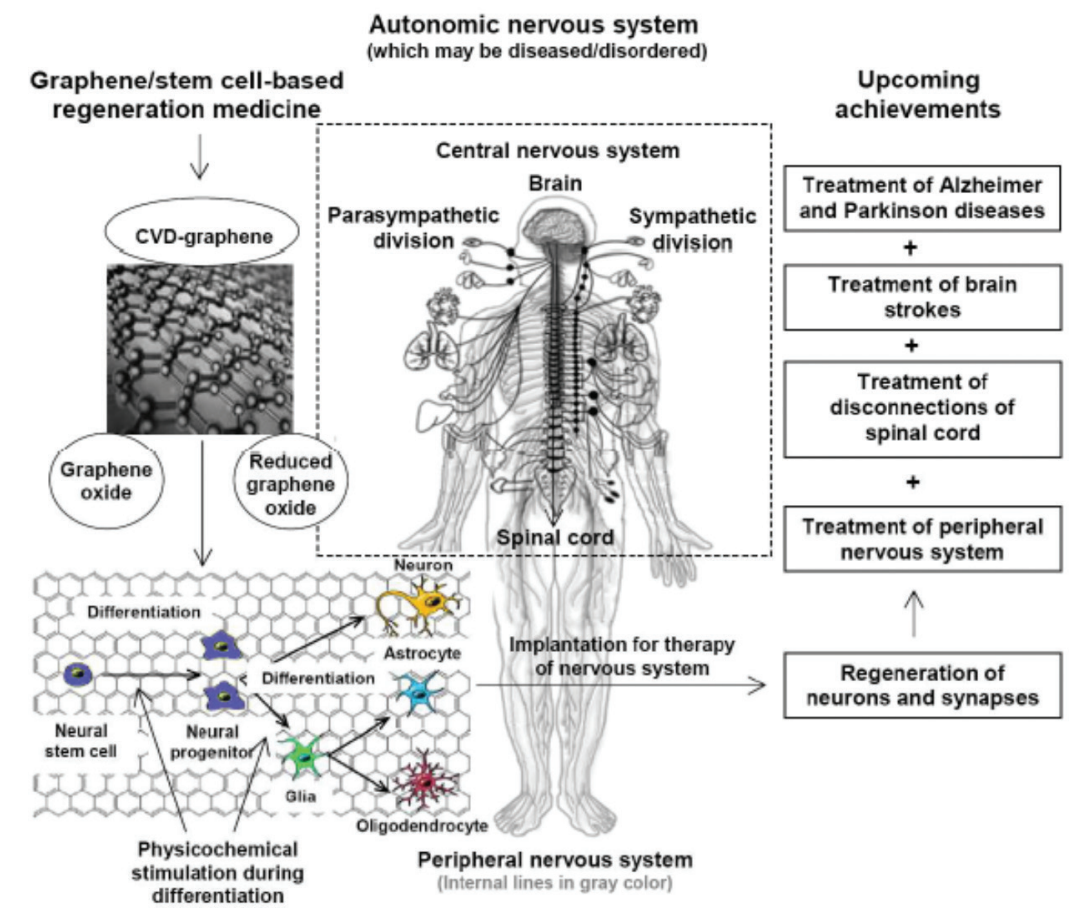

FIGURE 6. Schematic overview of the emerging potential of graphene/stem cell-based tissue engineering (Akhavan 2016) 
towards neurons than glial cells. Exceptional mechanical properties such as high strength and stiffness attribute graphene as a versatile material for differentiation of hNSC. This study exemplified that graphene platform is a viable to be used in stem cell therapy. In addition, this study showed that stem cell adhesion on graphene surface is stronger than that of the glass, in which allows more retention of NSCs on graphene. It is also worthy to note that the efficiency of differentiation of hNSC on graphene was higher than on quartz (glass) substrate (Figure 7). Akhavan et al. (2014) demonstrates that rGO films exhibits more differentiation of hNSCs than GO films. This better differentiation was attributed by hydrophilicity and $\Pi-\Pi$ attachment of ginsenoside molecules on the reduced sheets.

Graphene sheets (as 2-D scaffolds) have immense potential in cell proliferation and differentiation. However, for successful implementation of stem cells in clinical applications, namely regeneration of body organs and nervous system, 3-D scaffolds with desired topographies are preferred. Li et al. (2013) developed a novel scaffold which utilizes graphene foam as 3-D porous structure. This 3-D graphene foams were fabricated on $\mathrm{Ni}$ foam catalyst by chemical vapor deposition method. Li et al. (2013) reported that 3-D graphene foam not only is capable to support NSC growth, but also enhances proliferation of cells (by monitoring Ki67 expression, a cellular marker for proliferation) compared to CVD grown 2-D graphene sheets. Good electrical coupling was established in between 3-D graphene foam and differentiated cells. This study demonstrated the potential of graphene foam in NSCS research, neural tissue engineering and neural prostheses. Graphene was demonstrated to be an excellent platform to stem cell based tissue engineering especially for neural tissue engineering. Its flexibility and strength makes strong scaffolds with desired morphology, while extraordinary electrical, morphological and chemical properties promotes adhesion, differentiation and proliferation of various cells in stem cell based tissue engineering applications.

\section{GRAPHENE FOR POWERING IMPLANTABLE AND WEARABLE BIOMEDICAL AND DEVICES}

High power density, fast charging rate and extended life cycles have made supercapacitors favored to be used to power biomedical devices (Simon \& Gogotsi 2008). Graphene based supercapacitors has recently been explored to power biomedical devices as it has the ability to store high energy due to its extremely high surface area to mass ratio $\left(2630 \mathrm{~m}^{2} \mathrm{~g}^{-1}\right)$ (Lee et al. 2013). Much emphasis has been recently placed on research to investigate potential use of graphene as an active material in supercapacitors for effective energy storage (Kim et al. 2009).

In general, supercapacitors comprised of two electrodes located in an electrolyte medium and separated by a separator. In the presence of electrical energy, supercapacitor allows accumulation of opposite charges from electrolytes at the surface of dual electrodes to store energy (Figure 8) (Iro et al. 2016). The energy, E stored in the supercapacitor can be formulated as:

$$
E=\frac{1}{2} C V^{2}
$$

where $\mathrm{C}$ is the capacitance; and $\mathrm{V}$ is the operating voltage of supercapacitors (Abidin et al. 2011). Efficiency of a)

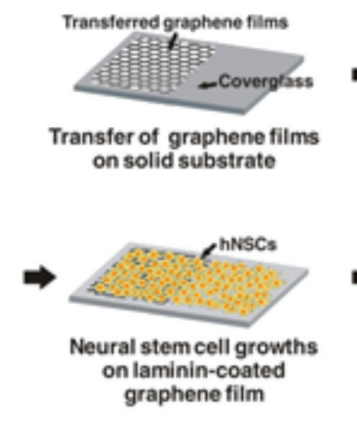

c)

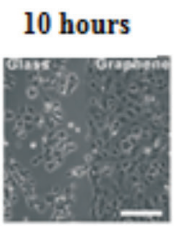

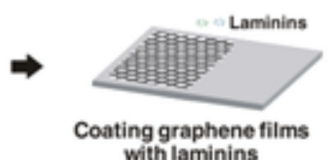

with laminins

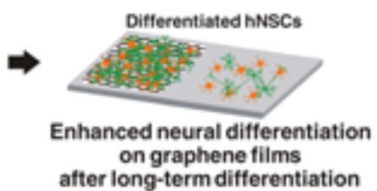

b)
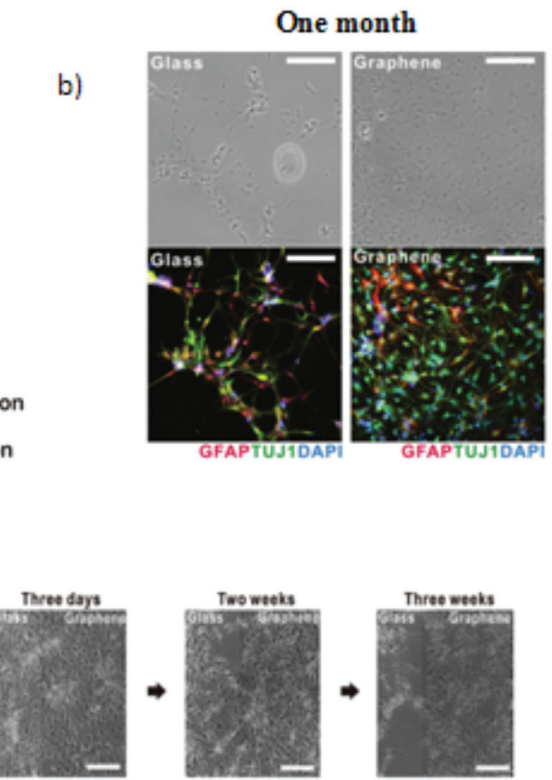
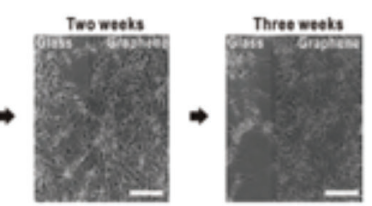

FIGURE 7. (a) Neural differentiation of hNSCs, (b) Enhanced neural differentiation on graphene films as evident by TUJ staining, (c) hNSCs grown more on graphene than glass, d) hNSCs on glass were gradually retracted and detached after two weeks, while those on graphene remained stable even after three weeks of differentiation (Park et al. 2011) 


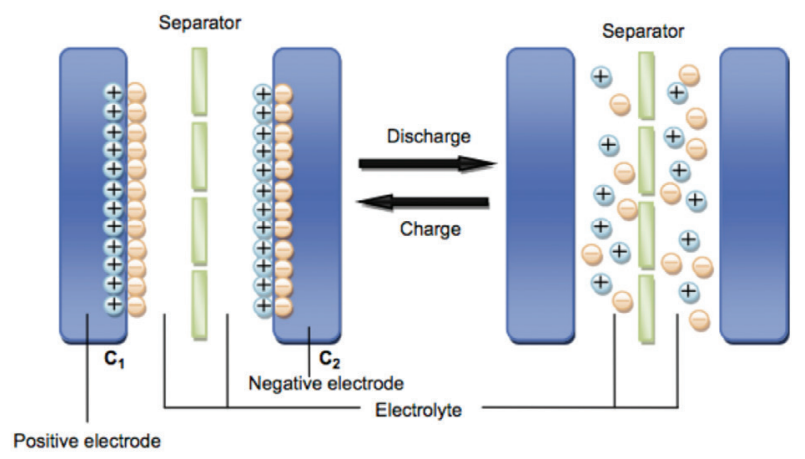

FIGURE 8. Working principle of superconductor when electrical field is applied (Li \& Wei 2013)

supercapacitors can be measured by energy density and power density. Energy density indicates the ability of superconductor to store energy and acts as power source, while power density measures the ability of a power unit to charge and discharge energy (Dreyer et al.2010). Study carried out by Liu et al. (2010a) showed that supercapacitors performance is influenced by morphological characteristics of graphene. They reported that curved graphene structures able to produce higher capacitance than flat graphene sheet (Figure 9). This is because curved graphene maintains the mesoporous structures and provides room for electrochemical accessibility of electrolytes which lead to faster diffusion rate. In contrast, flat graphene sheet tends to aggregate and prevents electrochemical double layer formation and reduces specific capacitance. In another study, researcher developed novel composites to increase effective surface area, so that aggregation effect can be overcome for better performance of supercapacitors (Wang et al. 2016).

Cheng et al. (2011) demonstrated the use carbon nanotubes (CNTs) to overcome graphene's aggregations effect for effective performance of supercapacitors. CNT acts as spacer and reduces resistance within the electrodes and allows ions to access pores of the graphene at higher charging rates (Figure 10). This eventually prevents graphene sheets from stacking on each other due to Van der Waals force during drying process; and acts as a binder to holds graphene sheets together. In recent studies, Wang et al. (2016) developed a novel method called modified molten-salt method to prepare molten salt method derived graphene (MNG) electrode with high capacitance and lowself discharge rate. MNG electrodes fabricated from this novel method prevents aggregation, restore conjugated network and provides a platform for nitrogen doping and activation in supercapacitors. (a)

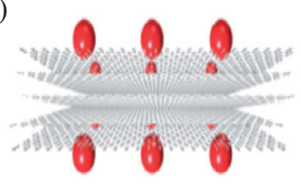

(b)

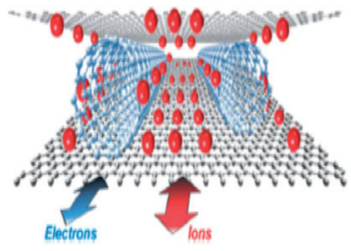

FIGURE 10. (a) Pristine graphene that undergoes aggregation and (b) graphene-CNT composite that acts as spacers and binders (Cheng et al. 2011)

Peng et al.(2015) demonstrated the use of laser induction technology to produce laser-induced graphene from polyimide films for the fabrication of 3-D supercapacitors, namely vertically stacked graphene supercapacitors and in-plane graphene microsupercapacitors. The stacked configuration of graphene increases the energy densities of the device which leads to superconductivity. It was also proven that, laser induction on both sides of polyimide films multiplies electrical performance of vertically stacked supercapacitors while preserving its device flexibility. This study highlights the capability of solidstate polymeric electrolyte-based devices in exhibiting areal capacitance of more than $9 \mathrm{mF} / \mathrm{cm}^{2}$ at a current density of $0.02 \mathrm{~mA} / \mathrm{cm}^{2}$, which is over twice that of conventional aqueous electrolytes (Peng et al. 2015). Abidin et al. (2015) demonstrated that interdigital electrodes achieved maximum current response which is $5.5 \mathrm{~A} / \mathrm{m}$ compared to planar electrodes which only exhibits $0.025 \mathrm{~A} / \mathrm{m}$. This study emphasized on the significance of electrodes structure in electrical performances of the microsupercapasitors. Surface area in interdigital electrodes are higher than planar electrodes and it provides more room for redox activities (a)

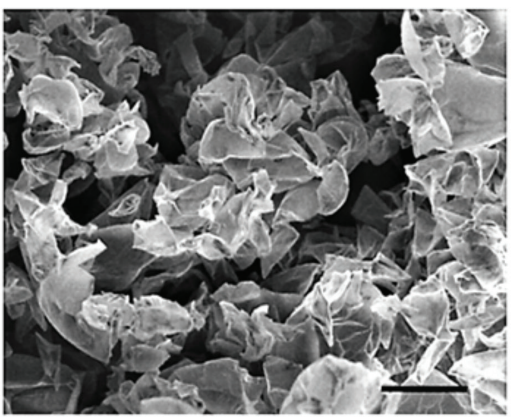

(b)

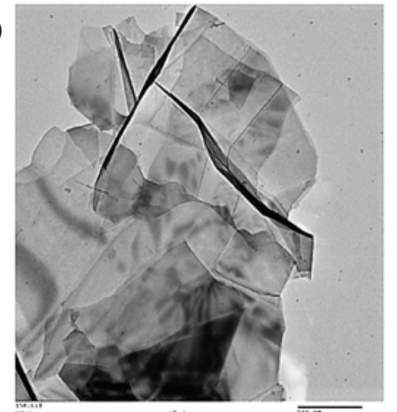

FIGURE 9. (a) SEM image of curved graphene sheets (scale bar 10 $\mu \mathrm{m}$ ) and (b) TEM image of flat graphene sheets (scale bar 500nm) (Liu et al. 2010b) 
between electrodes (Abidin et al. 2015). The group, which is from Universiti Kebangsaan Malaysia, is currently working on vertical graphene interdigital supercapacitor to power wearable and implantable biomedical devices. The graphene based supercapacitor would have higher energy and power densities compared to its conventional counterpart.

Researchers from California Nano Systems Institute recently announced hybrid energy storage which is a merge of batteries and supercapacitors. They combined laser-scribed graphene (LSG) with manganese oxide to fabricate microsupercapacitor which is just one-fifth the thickness of a sheet of paper. This minute device can be incorporated into wearable or implantable devices. Extreme temperatures or expensive fabrication processes were not implemented in the fabrication of the device. However, it holds six times higher energy capacity than that of commercially available supercapacitors and more than twice as much charge as thin-film lithium battery (Dubal et al. 2015). Graphene, with extremely high specific surface area (SSA) capable of achieving a capacitance up to $550 \mathrm{~F} / \mathrm{g}$ if it's entire SSA if fully accessed in supercapacitors (Liu et al. 2010a). Hence, the highest intrinsic capacitance and SSA favored graphene based supercapacitors as superior paradigm for powering biomedical devices.

\section{GRAPHENE IN BIOSENSORS}

Biosensors are defined by International Union of Pure and Applied Chemistry (IUPAC) as 'a device which uses specific biochemical reactions mediated by isolated enzymes, immunosystems, tissues, organelles or whole cells to detect chemical or biological compounds, usually by the use of electrical, thermal or optical signals'. They are prominent analytical tools in healthcare, environmental screening and monitoring food toxins and pathogens due to affordability and simplicity. Graphene provides significant advantages over current standards in biosensing due to its unique properties which are ultrahigh sensitivity and excellent stability. It demonstrated excellent transducing properties by transmitting signals to indicate presence of analytes in the environment with the assistance of bioreceptors (Figure 11).

Among the variety of electrical biosensing architectures, devices based on field effect transistors have attracted much attention. A typical planar field effect transistor (FET) consists of three metallic contact conducting electrodes which are the source(S), drain (D) and gate $(\mathrm{G})$ electrodes, thin insulating layer (dielectric) and semiconductor, latter being the active part where charge carriers flow (Figure 12) (Zhang \& Zheng 2015). The current carrying channel is in direct contact with environment and this provides better control on surface charge (Chaudhary et al. 2016). Therefore, surface based FET biosensors are more sensitive as it able to directly translate interactions of biological molecules on its surface into readable electrical signals (Cui 2013). Incorporating carbon nanomaterial especially graphene as sensing platform opens up opportunities for ultrasensitive, lowcost, low-noise and portable electrical biosensors for future device applications. The first top-gated graphene FET with on-off ratio less than 2 was fabricated in 2007 by Lemme et al. In this work, effect of top gate FET on carrier mobility of graphene was studied and compared with universal mobility of silicon and literature data of Silicon-On-Insulator (SOI) devices. This work showed that carrier mobilities of graphene top gate electrode exceed universal mobility of silicon and SOI, respectively. In addition, it also played significant role in modulation of drain current of FET and affects the performance of FET. Hence, graphene based transistors can operate twice the speed of comparable silicon transistors (Ali et al. 2015).

In 2009, researchers demonstrated the possibilities of realizing four basic two-input logic gates with a single graphene transistor. Graphene based transistors offers unique property to operate at charge neutrality points. This work offers attractive alternative for implementing logic gates operations as it offers minimal transistor count (Sordan et al. 2009). In addition, researchers at MIT Lincoln Lab demonstrated integration of hundreds of transistors on a single chip. Researchers discovered that a trend in the mobility of the device indicates the promising quality of graphene in future electronic technology. Minimum conduction between the source and drain is correlated with thickness of graphene film. Excellent thin film properties contribute to high carrier mobility and conduction of device. In contrast, in silicon technology mobility degrades as a function of thickness at nanometer scale (Kedzierski 2008). Therefore, graphene based devices offers high carrier mobility and provides excellent conductivity which make it more suitable to be used in electronic devices, especially in biosensors. Numerical simulations by Fiori and Iannaccone (2009) showed that nanoribbons or bilayer graphene with larger band gap

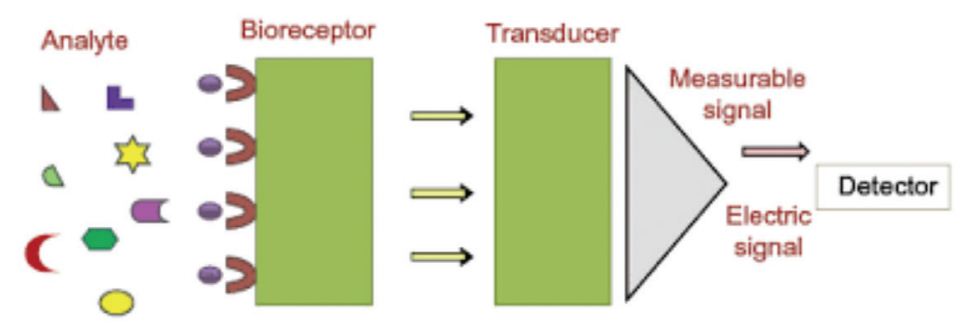

FIGURE 11. Schematic diagram illustrating working principles of biosensor (Amine et al. 2006) 

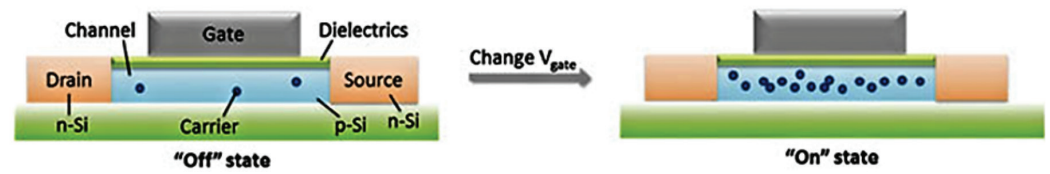

FIGURE 12. A typical planar field effect transistor (Zhang \& Zheng 2015)

than monolayer graphene in FET added advantage to its performance, especially in tunnel FET. Large ratios can be obtained for ultra-low voltage applications $(\sim 100 \mathrm{mV})$. This simulation proves that graphene based FET devices are more superior for biosensors as compared to other carbon nanomaterials such as carbon nanotubes (CNT) and nanowires. The random distribution of carbon nanotubes (CNT) across its substrate significantly restricts its feasibility in electronic devices and biosensing. CNTs are quite challenging to be manipulated during device fabrication, particularly in precise positioning on a chip (Kang et al. 2007). On the other hand, graphene is in planar form and offers larger detection area as compared to CNTs. This in turn allows highly developed topdown CMOS and compatible process flows (Lemme et al. 2007). In addition, sensitivity of CNT based devices are impaired by the presence of metallic tubes as it is difficult to separate metallic tubes from semiconducting CNTs. Moreover, graphene offers ease of functionality in biosensors as compared to CNT based biosensors. This is because functionalization of enzymes on the flat graphene is more effective and uniform than on small nanotubes. In contrary, functionalization steps on CNT alters the tubeto-tube contact and lead to loss of some nanotubes in the network (Huang et al. 2010).

In general, CNT based biosensors experienced microfluidic shock and drifted from its electrical performances as it's immersed in biological solutions. Lu et al. (2009) introduced a novel method to overcome this hurdle (Peng et al. 2015). In contrast, graphene based biosensors demonstrates ultrahigh sensitivity compared to 1-D CNTs. Its high quality two-dimensional (2-D) structures and crystal lattice screens charge fluctuations yields higher charge carrier mobilities and enables very low detection limit compared to CNT based sensors (Zhang \& Cui 2011). Yang et al. (2010) have discussed the significance of using graphene over carbon nanotubes (CNT) as transducing channel in biosensor design. Detection performances of graphene and carbon nanotubes based electronic biosensors, especially the FET type, are summarized in Table 2. Graphene demonstrates better sensitivity as its limit of detection is lower compared to carbon nanotubes for detection of analytes comprise of DNA, protein, small molecules and pathogens.

TABLE 2. Detection performances of graphene and carbon nanotubes based devices

\begin{tabular}{|c|c|c|c|}
\hline $\begin{array}{c}\text { Carbon } \\
\text { nanomaterials }\end{array}$ & Analyte & Limit of detection & Ref \\
\hline \multirow{15}{*}{ Graphene } & Glucose & 0.1 to $10 \mathrm{mM}$ & (Viswanathan et al. 2015) \\
\hline & Glucose & 0.1 to $10 \mathrm{mM}$ & (Viswanathan et al. 2015) \\
\hline & Nose target odorant & $0.04 \mathrm{fM}$ & (Mannoor et al. 2014) \\
\hline & Steroid hormone & $44.7 \mathrm{nM}$ & (Ping et al. 2015) \\
\hline & Nucleolin on cancer cell & One thousand cells & (Feng et al. 2011) \\
\hline & DNA & $10 \mathrm{fM}$ & (Ping et al. 2015) \\
\hline & DNA & $1 \mathrm{fM}$ & (Ping et al. 2016) \\
\hline & DNA & $3 \mathrm{nM}$ & (Guo et al. 2011) \\
\hline & DNA & $100 \mathrm{nM}$ & (Xu et al. 2014) \\
\hline & DNA & $1 \mathrm{pM}$ & (Ohno et al. 2010) \\
\hline & (Rakheja \& Sengupta 2016) & $13 \mathrm{pM}$ & (Mao et al. 2013) \\
\hline & $\operatorname{lgE}$ protein & $47 \mathrm{nM}$ & (Ohno et al. 2010) \\
\hline & $\operatorname{lgE}$ protein & $13 \mathrm{pM}$ & (Mao et al. 2013) \\
\hline & Prostate specific antigen & $0.11 \mathrm{fM}$ & (Zhang \& Cui 2011) \\
\hline & Arginine Vasopressin & $1 \mathrm{pM}-100 \mathrm{pM}$ & (Yang et al. 2016) \\
\hline \multirow{6}{*}{$\begin{array}{l}\text { Carbon } \\
\text { Nanotube } \\
(\mathrm{CNT})\end{array}$} & HRP & $0.4 \mathrm{ng} / \mathrm{mL}$ & (Lu et al. 2009) \\
\hline & Arginine Vasopressin & $43 \mathrm{pM}$ & (Nguyen et al. 2011) \\
\hline & Prostate specific antigen (PSA-ACT) complex & $1.0 \mathrm{ng} / \mathrm{mL}$ & (Kim et al. 2009) \\
\hline & H63D mutation in HFE gene & $1 \mathrm{pM}$ & (Star et al. 2006) \\
\hline & $\operatorname{lgE}$ protein & $250 \mathrm{pM}$ & (Chen et al. 2013) \\
\hline & Human $\lg G$ & $0.2 \mathrm{ng} / \mathrm{mL}$ & (Mao et al. 2011) \\
\hline
\end{tabular}


Recently, much efforts have been made to fabricate graphene based FET for DNA detection. In 2011, researchers from the University of California have fabricated graphene based FET for DNA detection. Graphene synthesized by chemical vapor deposition (CVD) was used as conducting medium as it has large surface area and provides higher sensitivity compared to graphene derived from mechanical exfoliation and chemical reduction. Graphene layer was functionalized with 1-Pyrenebutanoic acid succinimidyl ester to ensure high conductivity and sensitivity of the device. The device achieved detection limit as low as 3 $\mathrm{nM}$ (Guo et al. 2011). In another study, Chen et al. (2013) demonstrated a gold transfer technique to fabricate CVD grown graphene based FET for DNA detection. This novel technique eliminates the common defect (PMMA residues) as a result of conventional PMMA assisted transfer, which degrades the sensing performance of the graphene biosensor. Hence, detection limit down to $1 \mathrm{pM}$ was achieved in their work. In 2014, Xu et al. used amplification technique to fabricate graphene based FET to achieve $100 \mathrm{fM}$ detection limit. They demonstrated the usability of graphene as both electrodes and sensing elements in DNA detection. This approach opens up pathway for implementation of electrical multiplexed graphene DNA biosensor arrays. However, contamination of graphene surface and complex immobilization process limits the conductance of the graphene biosensor (Dong et al. 2010. In order to overcome this complication, Zheng et al. (2015) developed a novel method by introducing directional transfer technique to fabricate graphene based FET for DNA detection. Single layer graphene (SLG) obtained from chemical vapor deposition (CVD) technique was transferred to the sensor surface in directional manner. This technique provides solution to overcome contamination on graphene surface which was caused by conventional fabrication. This SLG FET achieved detection limit of $10 \mathrm{fM}$.

In recent studies, researchers reported development of scalable DNA biosensors based on back-gate graphene FET with detection limits as low as $1 \mathrm{fM}$. The use of graphene as transducing material and length of DNA oligomers attributes to the sensitivity of the sensor. Functionalization of the sensor with well-controlled chemical allows superior selectivity against non-complementary DNA oligomers. Surface area of the chemically treated sensor was fully covered with single stranded probe DNA, which leads to high selectivity of the device (Figure 13). The researchers discovered that graphene transferred by electrolysis bubbling method restricts contamination, doping and defects caused by graphene transferring process. Hence, this study overcome conventional limitation and paves the way for development of highly sensitive, selective and scalable DNA biosensors (Ping et al. 2015). The zero band gap property of graphene enables it to be used in FET based biosensors. Ohno et al. (2010) reported fabrication of FET using single layer graphene for selective electrical detection of $\lg$ E protein. They reported the dissociation constant of $47 \mathrm{nM}$ based on the variation of drain current in accordance with the concentration of $\operatorname{lgE}$ protein. This indicates the good affinity and reliability of graphene as a transducing medium in protein detection. Ohno et al. (2009) demonstrates the potential of graphene based FET in electrolyte medium for detection of bovine serum albumin (BSA). GFET immersed in an electrolyte demonstrates high transconductance ( $>30$ times) than in vacuum state and detection limit of $3 \mathrm{~nm}$ was achieved successfully. However, instability of Dirac point was reported due to contamination from the residue of EB resist and defects of $\mathrm{SiO}_{2}$.

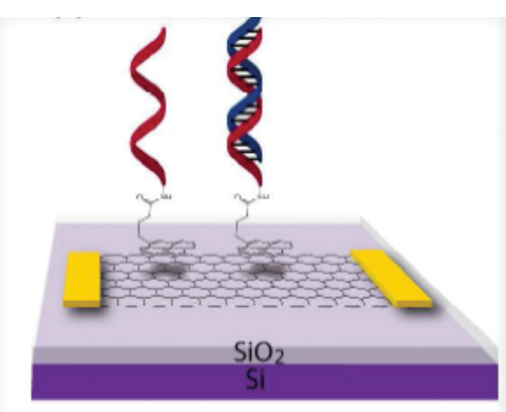

FIGURE 13. Surface area of chemically treated sensor was fully covered with single stranded probe DNA (Ping et al. 2016)

Zhang and Cui (2011) reported another approach in fabricating graphene based cancer biosensor for detection of prostate specific antigen (PSA) using layer-by-layer (LBL) self-assembly technique. The cancer sensor reported was fabricated on PET (Polyethylene terephthalate) flexible substrate with lithographic patterned gold electrodes. 1.5 wt. $\%$ poly diallydiamine chloride (PDDA), $0.3 \mathrm{wt}$ \% poly styrene sulfonate (PSS) and polyelectrolytes were used in this study, with an addition of $0.5 \mathrm{M}$ sodium chloride to enhance surface properties. The sensors were then immunized by immobilization of anti-PSA on the surface with label free method. Graphene based label free cancer sensor offers detection of PSA in large detection range from $4 \mathrm{fg} / \mathrm{mL}$ to $4 \mu \mathrm{g} / \mathrm{mL}$. As comparison, CNT sensor is only capable of detecting PSA of $4 \mathrm{ng} / \mathrm{mL}$. Ultrahigh sensitivity self-assembled graphene based biosensor could be achieved due to the following factors: Low electronic noise; the porous defoliation profile of selfassembled graphene promises more sensing area per unit volume; two dimensional crystal line structure. The results showed that detection limit and range of label free self-assembled graphene sensor exceed most of the existing detection techniques (Lu et al. 2009; Zheng et al. 2005). In another study, researchers explored strategies to overcome difficulties associated to direct detection of lowbiomolecular weight molecules in biosensing application. They utilize aptamers based competitive affinity assay in graphene based FET to detect small molecule steroid hormone dehydroepiandrosterone sulfate (DHEA-S). Aptamers hybridized on the surface of graphene undergoes disruption in the presence of DHEA-S hormones. This leads 
to changes in conductance of graphene and detection limit of $44.7 \mathrm{nM}$ was reported. This work demonstrated the usability of aptamers based competitive affinity assay for specific, sensitive and quantitative detection low weight biomolecules (Wang et al. 2015).

Recently, Mao et al. (2013) demonstrated fabrication of graphene based sensor with unique graphene morphology for sensitive detection of protein. Vertically orientated graphene $(\mathrm{VG})$ sheets were grown on FET sensor electrode through PECVD technique. Next,Au-NP antibody conjugates were deposited on its surface. Researchers showed that this method is simple, stable and repeatable compared to conventional drop-casting method which has high noise level and poor stability due to weak adhesion between graphene sheet and sensor electrodes. This VG FET sensors has low detection limit which of $\sim 2 \mathrm{ng} / \mathrm{mL}$ or $13 \mathrm{pM}$ and good response time as compared to graphene/CNT based electronic sensors. In another recent study, Gao et al. (2016) investigated performance of vertically grown CVD graphene in the detection of dopamine, guanine, uric acid and adenine. They reported that simultaneous detection of these four species was successfully achieved with low detection limit. VG CVD graphene exhibits high electro catalytic activities and resolved oxidation peaks of the species into four distinct peaks as it has large surface area and effects of edge structures. Therefore, VG graphene synthesized by PECVD techniques has large surface area for biomolecules interaction and highly conductive porous network for electrochemical reactions of analytes which makes it more feasible to be implemented in graphene based biosensing architectures (Ge et al. 2015; González et al. 2012; Hassan et al. 2014).

Graphene based sensors are also efficient in pathogen detection. Recently, Mannoor et al. (2014) printed graphene biosensor on a biodegradable silk substrate and placed it on tooth surface for pathogen detection. Self-assembly and disassembly of antimicrobial peptides on graphene surface was used to detect presence of pathogens. They discovered that coupling of these peptides and graphene nanosensor incorporated with resonant coil enables it to transmit signals for wireless detection. Changes in graphene resistance indicate the presence of pathogens (Figure 14). Types of receptors such as aptamers or antibodies immobilized on conducting channel for detection of target molecules influences biosensors performance, especially in FET architectures. Aptamers are synthetic short single stranded oligonucleotides composed of RNA or DNA, which exhibits exclusive properties that can substitute antibodies in specific detection of target molecules. Aptamers offer high sensitivity as it reduces screening effect and its length is within Debye length. Debye screening length is known as range or distance between immobilized target molecules and the surface of sensing platform which is separated by the screen of counter ion electrons attracted towards the sensing surface, called 'electrical double layer' (Figure 15) (Adzhri et al. 2016) A typical Debye length at room temperature is $5 \mathrm{~nm}$ in $5-10 \mathrm{mM}$ buffer solution (Ohno et al. 2010). Receptor and ligand reaction should occur within Debye length in order to ensure mobile charges on conducting channel are not affected by charges located outside Debye length. Therefore, receptors with height less than $5 \mathrm{~nm}$ are preferable to be immobilized on FET for sensing. Adzhri et al. (2016) experimentally studied the significance of length of probes on performance of FET sensor. They demonstrated that aptamer with shorter length than Debye screening effect length yields better conductivity and has higher performance (Figure 16) (Kang et al. 2007).

In comparison with antibodies, aptamers offers more advantages as promising receptor in functionalization

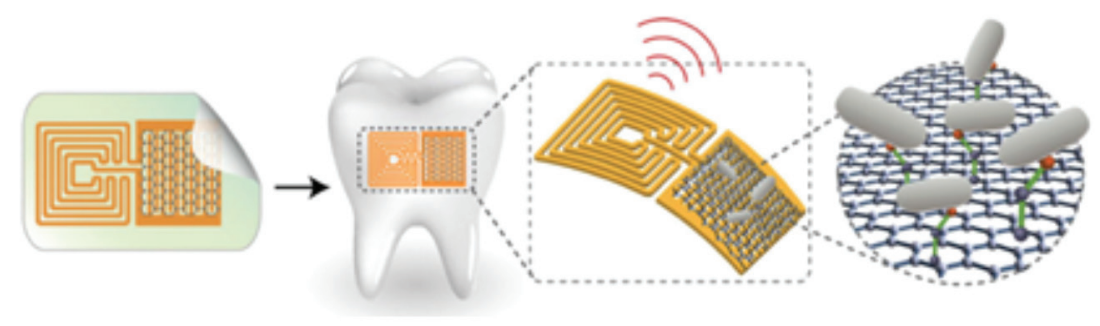

FIGURE 14. Graphene based biosensor fabricated on bioresorbable silk can be transferred on surface of tooth for bacteria detection (Mannoor et al. 2014)

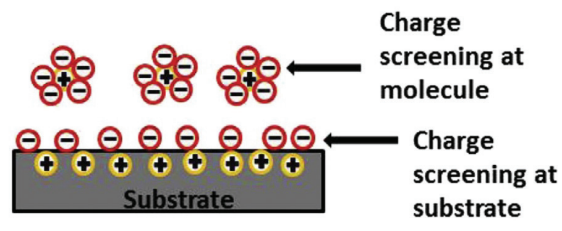

FIGURE 15. Effect of charge screening at the electrical potential of the device

(Adzhri et al. 2016) 


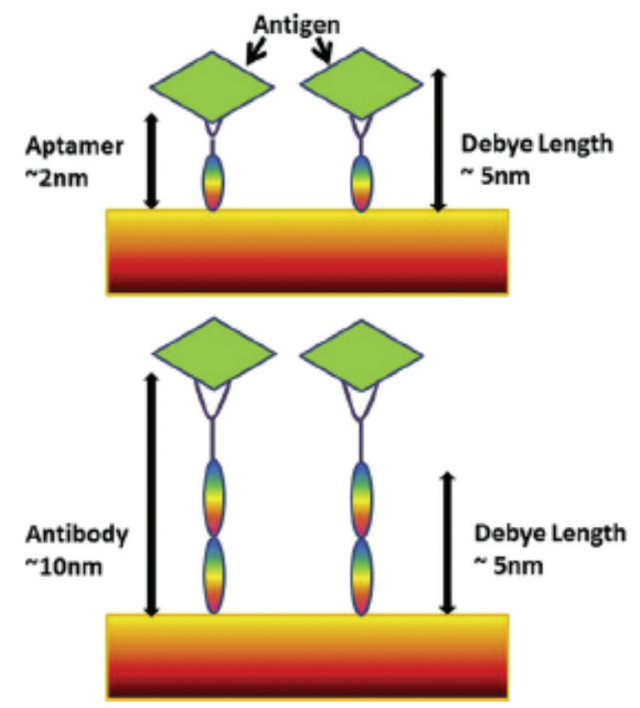

FIGURE 16. An aptamer-based immobilizer compared with an antibody-based immobilizer by Debye length. Shorter immobilizers yield better conductivity (Kang et al. 2007)

process. Aptamers are selected by in-vitro process namely systematic evolution of ligands by exponential enrichment (SELEX). Once the sequence is shown, these aptamers can be reproduced with high and consistent output by chemical synthesis method (Urmann et al. 2017). Hence, this results in mass production of aptamers with cost effective technique for functionalization process (Maehashi et al. 2007). Besides, aptamers are stable for long term storage as compared to antibodies, which are highly sensitive and denatured easily upon contact with surface. They can also be reproduced at $55^{\circ} \mathrm{C}$ and established sustainability of the sensor produced. Researchers in Universiti Kebangsaan Malaysia utilizes single layer graphene to produce FET based anti-diuretic hormone $(\mathrm{ADH})$ sensor to regulate body water content in patients using artificial kidney. Graphene serves as a conducting channel in the FET biosensor. Receptors immobilized on graphene surface captures targeted analytes. The adsorption of molecular analytes on the immobilized receptors generates changes in graphene conductivity which can be determined by measuring drain current in the FET. Therefore, conductance changes in graphene used as a tool to detect presence of targeted analytes in blood. This in turn would enable the sensor to regulate and control body water content in patients treated using dialysis or artificial kidney.

Transconductance of conventional FET depends linearly on gate voltage or surface potential. In sub-threshold regime, device conductance depends exponentially on gate voltage and results in higher analyte binding sensitivity. Gao et al. (2016) compared and studied the sensitivity of FET $\mathrm{pH}$ sensor in both linear and sub-threshold regimes. Absolute signal change of conductance, $\Delta \mathrm{G}$ in sub-threshold regime is small and it does not reflect the intrinsic device sensitivity. Hence, the group introduced dimensionless parameter $\Delta \mathrm{G} / \mathrm{G}$ to compare device sensitivities. Figure 17 shows that device undergoes much larger change in subthreshold regime than in other medium. Therefore, this work showed that as noise is exponentially reduced in this regime, significant enhancement of sensitivity is capable of achieving in subthreshold regime (Zhang \& Zheng 2015). Hence, subthreshold regime is a promising regime to measure the performance of the FET sensors for biosensing. In general, graphene has been demonstrated by various groups to be a highly promising material to be implemented in highly sensitive biosensors for various biological molecules detection.

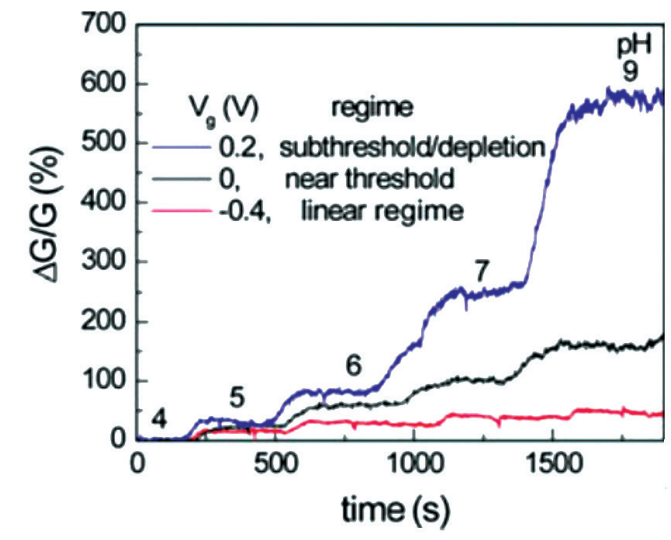

FIGURE 17. Real time $\mathrm{pH}$ sensing. The device in the sub threshold regime shows much larger $\Delta \mathrm{G} / \mathrm{G}$ change versus $\mathrm{pH}$ (Zheng et al. 2015)

\section{CONCLUSION}

This paper highlights the unique properties of graphene and its potential as an enticing material for biomedical applications. By taking advantage of graphene strength, the material has been utilized as scaffolding to regenerate and restore tissues and organs efficiently. On the other hand, graphene's high surface to mass ratio and superior electrical conductivity enables it to be used in supercapacitors to power up biomedical devices. The ultrahigh sensitivity of graphene makes it possible to be used in transducing channel for the detection of analytes in biosensors. Despite this remarkable progress, graphene based biosensors particularly GFET has yet to be commercialized. This is due to device-to-device heterogeneity of electronic properties (Liu \& Guo 2012) and difficulty in incorporating individual sensors in functional devices. In addition, conventional measurements of graphene based biosensors are carried out by ideal medium such as pure buffer solutions, whereas real biological samples are exposed to interference and fouling effects. Toxicological assessment has to be taken into consideration before applying graphene biosensors in biomedical applications. Nonetheless, graphene promises unique applications in the biomedical field, that implementation could be materialized and publicly used in decades to come. 


\section{ACKNOWLEDGEMENTS}

The authors would like to thank the Ministry of Higher Education (MoHE), Malaysia for the HiCoE MEMS for Artificial Kidney (AKU95) and LRGS/2015/UKM-UKM/ NANOMITE/04/01 grants used in this project.

\section{REFERENCES}

Abidin, H.E.Z., Hamzah, A.A., Mohamed, M.A., Majlis, B.Y. \& Marsi, N. 2015. Electrical performances based on two different structured of micro supercapacitor electrodes. IEEE Regional Symposium on Micro and Nano Electronics (RSM) 4: 5-8. doi:10.1109/RSM.2015.7354977.

Abidin, H.E.Z., Hamzah, A.A. \& Majlis, B.Y. 2011. Design of interdigital structured supercapacitor for powering biomedical devices. 2011 IEEE Regional Symposium on Micro and Nanoelectronics, RSM 2011 - Programme and Abstracts.pp. 88-91. doi:10.1109/RSM.2011.6088298.

Adzhri, R., Md Arshad, M.K., Gopinath, S.C.B., Ruslinda,A.R., Fathil, M.F.M., Ayub, R.M., M. Nuhaizan, Mohd Nor \& Voon, C.H. 2016. High-performance integrated field-effect transistor-based sensors. Analytica Chimica Acta 917: 1-18. doi:10.1016/j.aca.2016.02.042.

Ahadian, S., Obregón, R., Ramón-Azcón, J., Salazar, G., Shiku, H., Ramalingam, M. \& Matsue, T. 2016. Carbon nanotubes and graphene-based nanomaterials for stem cell differentiation and tissue regeneration. Journal of Nanoscience and Nanotechnology 16(9): 8862-8880. doi:10.1166/jnn.2016.12729.

Akhavan, O. 2016. Graphene scaffolds in progressive nanotechnology/stem cell-based tissue engineering of nervous systems. J. Mater. Chem. B 4: 3169-3190. doi:10.1039/C6TB00152A.

Akhavan, O., Ghaderi, E., Abouei, E., Hatamie, S. \& Ghasemi, E. 2014. Accelerated differentiation of neural stem cells into neurons on ginseng-reduced graphene oxide sheets. Carbon 66: 395-406. doi:10.1016/j.carbon.2013.09.015.

Ali, U., Karim, K.J.B.A. \& Buang, N.A. 2015. A review of the properties and applications of poly(methyl methacrylate) (PMMA). Polymer Reviews 55(10): 678-705. doi:10.1080/ 15583724.2015.1031377.

Amine, A., Mohammadi, H., Bourais, I. \& Palleschi, G. 2006. Enzyme inhibition-based biosensors for food safety and environmental monitoring. Biosensors and Bioelectronics 21(8): 1405-1423. doi:10.1016/j.bios.2005.07.012.

Bae, S., Kim, H., Lee, Y., Xu, X., Park, J.-S., Zheng, Y., Balakrishnan, J., Lei, T., Kim, H.R., Song, Young II, Kim, Y-K., Kim, K.S., Özyilmaz, B., Ahn, J-H., Hong, B.H. \& Iijima, S. 2010. Roll-to-roll production of 30-inch graphene films for transparent electrodes. Nature Nanotechnology 5(8): 574-578. doi:10.1038/nnano.2010.132.

Castro Neto, A.H., Guinea, F., Peres, N.M.R., Novoselov, K.S. \& Geim, A.K. 2009. The electronic properties of graphene. Reviews of Modern Physics 81(1): 109-162. doi:10.1103/ RevModPhys.81.109.

Chaudhary, R., Sharma, A., Sinha, S., Yadav, J., Sharma, R., Mukhiya, R. \& Khanna, V.K. 2016. Fabrication and characterisation of Al gate n-metal-oxide-semiconductor field-effect transistor, on-chip fabricated with silicon nitride ion-sensitive field-effect transistor. IET Computers and Digital Techniques 10(5): 268-272. doi:10.1049/ietcdt.2015.0174.
Chen, T-Y., Loan, P.T.K., Hsu, C-L., Lee, Y-H., Wang, J. T-W., Wei, K-H., Lin, C-T. \& Li, L.J. 2013. Label-free detection of DNA hybridization using transistors based on CVD grown graphene. Biosensors \& Bioelectronics 41: 103-109. doi:10.1016/j.bios.2012.07.059.

Cheng, Q., Tang, J., Ma, J., Zhang, H., Shinya, N. \& Qin, L.C. 2011. Graphene and carbon nanotube composite electrodes for supercapacitors with ultra-high energy density. Physical Chemistry Chemical Physics 13(39): 17615-17624. doi:10.1039/c1cp21910c.

Choi, W., Lahiri, I., Seelaboyina, R. \& Kan, Y.S. 2010. Synthesis of graphene and its applications: A review. Critical Reviews in Solid State and Materials Sciences 35(1): 52-71. doi:10.1080/10408430903505036.

Craciun, M.F., Russo, S., Yamamoto, M. \& Tarucha, S. 2011. Tuneable electronic properties in graphene. Nano Today 6(1): 42-60. doi:10.1016/j.nantod.2010.12.001.

Cui, Y. 2013. Nanowire nanosensors for highly sensitive and selective detection of biological and chemical species. Science 293(5533): 1289-1292. doi:10.1126/science.1062711.

Dong, X., Shi, Y., Huang, W., Chen, P. \& Li, L.J. 2010. Electrical detection of DNA hybridization with single-base specificity using transistors based on CVD-grown graphene sheets. Advanced Materials 22(14): 1649-1653. doi:10.1002/ adma.200903645

Dreyer, D.R., Ruoff, R.S. \& Bielawski, C.W. 2010. From conception to realization: An historial account of graphene and some perspectives for its future. Angewandte Chemie - International Edition 49(49): 9336-9344. doi:10.1002/ anie. 201003024.

Dubal, D.P., Ayyad, O., Ruiz, V. \& Gómez-Romero, P. 2015. Hybrid energy storage: The merging of battery and supercapacitor chemistries. Chem. Soc. Rev. 44(7): 17771790. doi:10.1039/C4CS00266K.

Feng, L., Chen, Y., Ren, J. \& Qu, X. 2011. A graphene functionalized electrochemical aptasensor for selective label-free detection of cancer cells. Biomaterials 32(11): 2930-2937. doi:10.1016/j.biomaterials.2011.01.002.

Fiori, G. \& Iannaccone, G. 2009. Ultralow-voltage bilayer graphene tunnel FET. IEEE Electron Device Letters 30(10): 1096-1098. doi:10.1109/LED.2009.2028248.

Gao, D., Li, M., Li, H., Li, C., Zhu, N. \& Yang, B. 2016. Sensitive detection of biomolecules and DNA bases based on graphene nanosheets. Journal of Solid State Electrochemistry 21(3): 813-821. doi:10.1007/s10008-016-3423-0.

Ge, C., Li, H., Li, M., Li, C., Wu, X. \& Yang, B. 2015. Synthesis of a $\mathrm{ZnO}$ nanorod/CVD graphene composite for simultaneous sensing of dihydroxybenzene isomers. Carbon 95: 1-9. doi:10.1016/j.carbon.2015.08.006.

Innova Research. 2015. Overcapacity will soon reshape graphene industry landscape. https://www.newswire.com/ news/overcapacity-will-soon-reshape-graphene-productionlandscape. Accessed on February 6, 2017.

Novoselov, K.S., Jiang, Z., Zhang, Y., Morozov, S.V., Stormer, H.L., Zeitler, U., Maan, J.C., Boebinger, G.S., Kim, P. \& Geim, A.K. 2007. Room temperature quantum hall effect in graphene. Science 315(5817): 1379. DOI: 10.1126/ science. 1137201

Goenka, S., Sant, V. \& Sant, S. 2014. Graphene-based nanomaterials for drug delivery and tissue engineering. Journal of Controlled Release 173(1): 75-88. doi:10.1016/j. jconrel.2013.10.017. 
González,Z., Vizireanu, S., Dinescu, G., Blanco,C.\& Santamaría, R. 2012. Carbon nanowalls thin films as nanostructured electrode materials in vanadium redox flow batteries. Nano Energy 1(6): 833-839. doi:10.1016/j.nanoen.2012.07.003.

Guo, S.R., Lin, J., Penchev, M., Yengel, E., Ghazinejad, M., Ozkan, C.S. \& Ozkan, M. 2011. Label free DNA detection using large area graphene based field effect transistor biosensors. Journal of Nanoscience and Nanotechnology 11(6): 5258-5263. doi:10.1166/jnn.2011.3885.

Hass, J., de Heer, W.A. \& Conrad, E.H. 2008. The growth and morphology of epitaxial multilayer graphene. Journal of Physics: Condensed Matter 20(32): 323202. doi:10.1088/0953-8984/20/32/323202.

Hassan, S., Suzuki, M., Mori, S. \& El-Moneim,A.A. 2014.MnO2/ carbon nanowalls composite electrode for supercapacitor application. Journal of Power Sources 249(January): 21-27. doi:10.1016/j.jpowsour.2013.10.097.

Huang, Y., Dong, X., Shi, Y., Li, C.M., Li, L.J. \& Chen, P. 2010. Nanoelectronic biosensors based on CVD grown graphene. Nanoscale 2(8): 1485-1488. doi:10.1039/c0nr00142b.

Hwang, J., Yoon, T., Jin, S.H., Lee, J., Kim, T.S., Hong, S.H. \& Jeon, S. 2013. Enhanced mechanical properties of graphene/copper nanocomposites using a molecular-level mixing process. Advanced Materials 25(46): 6724-6729. doi:10.1002/adma.201302495.

Kang, S.J., Kocabas, C., Ozel, T., Shim, M., Pimparkar, N.,Alam, M.A., Rotkin, S.V. \& Rogers, J.A. 2007. High-performance electronics using dense, perfectly aligned arrays of singlewalled carbon nanotubes. Nature Nanotechnology 2(4): 230-236. doi:10.1038/nnano.2007.77.

Kedzierski, J. 2008. Epitaxial graphene transistors on SiC substrates. IEEE Trans. Electron Devices, 55(8): 2078-2085. http://dx.doi.org/10.1109/TED.2008.926593.

Kim, J.P., Lee, B.Y., Lee, J., Hong, S. \& Sim, S.J. 2009. Enhancement of sensitivity and specificity by surface modification of carbon nanotubes in diagnosis of prostate cancer based on carbon nanotube field effect transistors. Biosensors and Bioelectronics 24(11): 3372-3378. doi:10.1016/j.bios.2009.04.048.

Lee, S.K., Kim, H. \& Shim, B.S. 2013. Graphene: An emerging material for biological tissue engineering. Carbon Letters 14(2): 63-75. doi:10.5714/CL.2013.14.2.063.

Lemme, M.C., Member, S., Echtermeyer, T.J., Baus, M. \& Kurz, H. 2007. A graphene field-effect device. IEEE Electron Device Letters 28(4): 282-284.

Li, N., Zhang, Q., Gao, S., Song, Q., Huang, R., Wang, L., Liu, L., Dai, J., Tang, M. \& Cheng, G. 2013. Three-dimensional graphene foam as a biocompatible and conductive scaffold for neural stem cells. Scientific Reports 3: 1604. doi:10.1038/ srep01604.

Li, X. \& Wei, B. 2013. Supercapacitors based on nanostructured carbon. Nano Energy 2(2): 159-173. doi:10.1016/j. nanoen.2012.09.008

Liu, C., Yu, Z., Neff, D., Zhamu, A. \& Jang, B.Z. 2010a. Graphene-based supercapacitor with an ultrahigh energy density. Nano Letters 10(12): 4863-4868. doi:10.1021/ nl102661q.

Liu, C., Yu, Z., Neff, D., Zhamu, A. \& Jang, B.Z. 2010b. Graphene-based supercapacitor with an ultrahigh energy density - SI. Nano Letters 10(12): 4863-4868. doi:10.1021/ nl102661q.

Liu, S. \& Guo, X. 2012. Carbon nanomaterials field-effecttransistor-based biosensors. NPG Asia Materials 4(8): e23. doi:10.1038/am.2012.42.
Lu, M., Lee, D., Xue, W. \& Cui, T. 2009. Flexible and disposable immunosensors based on layer-by-layer self-assembled carbon nanotubes and biomolecules. Sensors and Actuators A: Physical 150(2): 280-285. doi:10.1016/j.sna.2008.12.021.

Lund, A.W., Yener, B., Stegemann, J.P. \& Plopper, G.E. 2009. The natural and engineered 3D microenvironment as a regulatory cue during stem cell fate determination. Tissue Engineering. Part B, Reviews 15(3): 371-380. doi:10.1089/ ten.teb.2009.0270.

Maehashi, K., Katsura, T., Kerman, K., Takamura, Y., Matsumoto, K. \& Tamiya, E. 2007. Label-free protein biosensor based on aptamer-modified carbon nanotube field-effect transistors. Analytical Chemistry 79(2): 782-787. doi:10.1021/ ac060830g.

Mannoor, M.S., Tao, H., Clayton, J.D., Sengupta, A., Kaplan, D.L., Naik, R.R., Verma, N., Omenetto, F.G. \& McAlpine, M.C. 2014. Graphene-based wireless bacteria detection on tooth enamel. Nature Mater. XXXIII(2): 81-87.doi:10.1007/ s13398-014-0173-7.2.

Mao, S., Yu, K., Chang, J., Steeber, D.A., Ocola, L.E. \& Chen, J. 2013. Direct growth of vertically-oriented graphene for field-effect transistor biosensor. Scientific Reports 3: 1696. doi:10.1038/srep01696.

Mao, S., Yu, K., Lu, G. \& Chen, J. 2011. Highly sensitive protein sensor based on thermally-reduced graphene oxide fieldeffect transistor. Nano Research 4(10): 921-930. doi:10.1007/ s12274-011-0148-3.

Nguyen, T., Pei, R., Landry, D.W., Stojanovic, M.N. \& Lin, Q. 2011. Microfluidic aptameric affinity sensing of vasopressin for clinical diagnostic and therapeutic applications. Sensors and Actuators B: Chemical 154(1): 59-66. doi:10.1016/j. snb.2009.10.032.

Ohno, Y., Maehashi, K. \& Matsumoto, K. 2010. Label-free biosensors based on aptamer-modified graphene field-effect transistors. Journal of the American Chemical Society 132(51): 18012-18013. doi:10.1021/ja108127r.

Ohno, Y., Maehashi, K., Yamashiro, Y. \& Matsumoto, K. 2009. Electrolyte-gated graphene field-effect transistors for detecting $\mathrm{pH}$ and protein adsorption. Nano Lett. 9(9): 3318-3322.

Park, S.Y., Park, J., Sim, S.H., Sung, M.G., Kim, K.S., Hong, B.H. \& Hong, S. 2011. Enhanced differentiation of human neural stem cells into neurons on graphene. Advanced Materials 23(36): 263-267. doi:10.1002/adma.201101503.

Pei, S. \& Cheng, H.M. 2012. The reduction of graphene oxide. Carbon 50(9): 3210-3228. doi:10.1016/j.carbon.2011.11.010.

Peng, Z., Lin, J., Ye, R., Samuel, E.L.G. \& Tour, J.M. 2015. Flexible and stackable laser-induced graphene supercapacitors. ACS Applied Materials and Interfaces 7(5): 3414-3419. doi:10.1021/am509065d.

Peres, N.M.R. 2009. The electronic properties of graphene and its bilayer. Vacuum 83(10): 1248-1252. doi:10.1016/j. vacuum.2009.03.018.

Ping, J., Vishnubhotla, R., Vrudhula, A. \& Johnson, A.T.C. 2016. Scalable production of high sensitivity, label-free DNA biosensors based on back-gated graphene field effect transistors. ACS Nano acsnano.6b04110. doi:10.1021/ acsnano.6b04110.

Ping, J., Zhou, Y., Wu, Y., Papper, V., Boujday, S., Marks, R.S. \& Steele, T.W.J. 2015. Recent advances in aptasensors based on graphene and graphene-like nanomaterials. Biosensors and Bioelectronics 64: 373-385. doi:10.1016/j.bios.2014.08.090. 
Rakheja, S. \& Sengupta, P. 2016. Gate-voltage tunability of plasmons in single-layer graphene structures - Analytical description, impact of interface states, and concepts for terahertz devices. IEEE Transactions on Nanotechnology 15(1): 113-121. doi:10.1109/TNANO.2015.2507142.

Ren, W. \& Cheng, H. 2014. The global growth of graphene. Nature Nanotechnology 9: 726-730. doi:10.1038/nnano.2014.229.

Iro, Z.S., Subramani, C. \& Dash, S.S. 2016. A brief review on electrode materials for supercapacitor. International Journal of Electrochemical Science 11: 10628-10643. doi: $10.20964 / 2016.12 .50$.

Simon, P. \& Gogotsi, Y. 2008. Materials for electrochemical capacitors. Nature Materials 7(11): 845-854. doi:10.1038/ nmat2297.

Sordan, R., Traversi, F. \& Russo, V. 2009. Logic gates with a single graphene transistor. Applied Physics Letters 94: 073305. doi:10.1063/1.3079663.

Star, A., Tu, E., Niemann, J., Gabriel, J.C.P., Joiner, C.S. \& Valcke, C. 2006. Label-free detection of DNA hybridization using carbon nanotube network field-effect transistors. Proceedings of the National Academy of Sciences 103(4): 921-926. doi:10.1073/pnas.0504146103.

Tan, Y.B. \& Lee, J.M. 2013. Graphene for supercapacitor applications. Journal of Materials Chemistry A 1(47): 1481414843. doi:10.1039/c3ta12193c

Taychatanapat, T., Watanabe, K., Taniguchi, T. \& Jarillo-Herrero, P. 2011. Quantum hall effect and Landau level crossing of Dirac fermions in trilayer graphene. Nature Physics 7(8): 621-625. doi:10.1038/nphys2008.

Tran, T.T. \& Mulchandani, A. 2016. Carbon nanotubes and graphene nano field-effect transistor-based biosensors. Trends in Analytical Chemistry 79: 222-232. doi:10.1016/j. trac.2015.12.002.

Urmann, K., Modrejewski, J. \& Scheper, T. 2017. Aptamermodified nanomaterials: Principles and applications. BioNanoMat 18(1-2): 20160012. doi:10.1515/bnm-20160012 .

Viswanathan, S., Narayanan, T.N., Aran, K., Fink, K.D., Paredes, J., Ajayan, P.M., Filipek, S., Miszta, P., Cumhur Tekin, H., Inci, F., Demirci, U., Li, P., Bolotin, K.I., Liepmann, D. \& Renugoplakrishnan, V. 2015. Graphene-protein field effect biosensors: Glucose sensing. Materials Today 18(9): 513-522. doi:10.1016/j.mattod 2015.04 .003 .

Wang, C., Kim, J., Zhu, Y., Yang, J., Lee, G.H., Lee, S., Yu, J., Pei, R., Liu, G., Nuckolls, C. Hone, J. \& Lin, Q. 2015. An aptameric graphene nanosensor for label-free detection of small-molecule biomarkers. Biosensors and Bioelectronics 71: 222-229. doi:10.1016/j.bios.2015.04.025.

Wang, J., Ding, B., Hao, X., Xu, Y., Wang, Y., Shen, L., Dou, H. \& Zhang, X. 2016. A modified molten-salt method to prepare graphene electrode with high capacitance and low self-discharge rate. Carbon 102: 255-261. doi:10.1016/j. carbon.2016.02.047.

Wang, Y., Wang, Y., Chen, J., Guo, H., Liang, K., Marcus, K., Peng, Q.L., Zhang, J. \& Feng, Z.S. 2016. A facile process combined with inkjet printing, surface modification and electroless deposition to fabricate adhesion-enhanced copper patterns on flexible polymer substrates for functional flexible electronics. Electrochimica Acta 218: 24-31. doi:10.1016/j. electacta.2016.08.143.
Xu, G., Abbott, J., Qin, L., Yeung, K.Y.M., Song, Y., Yoon, H., Kong, J. \& Ham, D. 2014. Electrophoretic and field-effect graphene for all-electrical DNA array technology. Nature Communications 5: 4866. doi:10.1038/ncomms5866.

Yan, F., Zhang, M. \& Li, J. 2014. Solution-gated graphene transistors for chemical and biological sensors. Advanced Healthcare Materials 3(3): 313-331. doi:10.1002/ adhm.201300221.

Yang, F., Murugan, R., Wang, S. \& Ramakrishna, S. 2005. Electrospinning of nano/micro scale poly(l-lactic acid) aligned fibers and their potential in neural tissue engineering. Biomaterials 26(15): 2603-2610. doi:10.1016/j. biomaterials.2004.06.051.

Yang, J., Zhu, J., Pei, R., Oliver, J.A., Landry, D.W., Stojanovic, M.N. \& Lin, Q. 2016. Integrated microfluidic aptasensor for mass spectrometric detection of vasopressin in human plasma ultrafiltrate. Analytical Methods 8(26): 5190-5196. doi:10.1039/c5ay02979a.

Yang, W., Ratinac, K.R., Ringer, S.R., Thordarson, P., Gooding, J.J. \& Braet, F. 2010. Carbon nanomaterials in biosensors: Should you use nanotubes or graphene. Angewandte Chemie - International Edition 49(12): 2114-2138. doi:10.1002/ anie. 200903463.

Zhang, A. \& Zheng, G. 2015. Semiconductor nanowires for biosensors. In Semiconductor Nanowires: Materials, Synthesis, Characterization and Applications. Cambridge: Woodhead Publishing. pp. 471-490. doi:10.1016/B978-178242-253-2.00017-7.

Zhang, B. \& Cui, T. 2011. An ultrasensitive and low-cost graphene sensor based on layer-by-layer nano self-assembly. Applied Physics Letters 98(7): 2011-2014. doi:10.1063/1.3557504.

Zheng, C., Huang, L., Zhang, H., Sun, Z., Zhang, Z. \& Zhang, G.J. 2015. Fabrication of ultrasensitive field-effect transistor DNA biosensors by a directional transfer technique based on CVD-grown graphene. ACS Applied Materials and Interfaces 7(31): 16953-16959. doi:10.1021/acsami.5b03941.

Zheng, G., Patolsky, F., Cui, Y., Wang, W.U. \& Lieber, C.M 2005. Multiplexed electrical detection of cancer markers with nanowire sensor arrays. Nature Biotechnology 23(10): 1294-1301. doi:10.1038/nbt1138.

Institute of Microengineering and Nanoelectronics (IMEN)

Universiti Kebangsaan Malaysia

43600 UKM Bangi, Selangor Darul Ehsan

Malaysia

*Corresponding author; email: azlanhamzah@ukm.edu.my

Received: 27 December 2016

Accepted: 13 February 2017 